\title{
Situating Arab-Israeli artisanal fishermen's perceptions of marine litter in a socio- institutional and socio-cultural context
}

\author{
Ruth E. Brennan ${ }^{a}$, Michelle E. Portman ${ }^{b}$ \\ a Technion - Israel Institute of Technology, Faculty of Architecture and Town Planning, \\ Technion City, Haifa 3200003, Israel \\ b Technion - Israel Institute of Technology, Faculty of Architecture and Town Planning, \\ Technion City, Haifa 3200003, Israel
}

This is the accepted manuscript of a paper originally published in Marine Pollution Bulletin. You may find the final, formatted version at 10.1016/i.marpolbul.2016.12.001.

\section{Abstract}

Understanding the mental constructs underlying people's social responses, decisions and behaviors is crucial to defining the governance challenges faced in dealing with marine anthropogenic litter. Using interactive governance theory, this study provides qualitative insights into how a small group of Arab-Israeli artisanal fishermen perceive marine litter and its impact (system to be governed) in the context of the socio-institutional structures (governing system) which manage waste and aim to protect the surrounding environment. It demonstrates that, until the relationships between local people and the various governing institutions are transformed, there is little hope for citizen cooperation in reducing marine litter long-term in the case-study site. More generally, underlying narratives and politics playing out at a local level need to be understood in order to identify which interventions are likely to be effective and which are not. An intervention checklist to assess the potential effectiveness of a marine litter intervention is proposed.

\section{Background}

Dealing with marine litter involves grappling with a complex social- ecological system which involves diverse and dynamic interactions at various scales between, and within, natural and social systems. Defined as "any persistent, manufactured or processed solid material discarded, disposed of, or abandoned in the marine and coastal environment", marine litter poses a threat to the environment, economy and human health (UNEP, 2009). Plastic items make up 50-80\% of marine litter found on the beaches of the four European regional seas (Mediterranean Sea, Black Sea, North-East Atlantic and Baltic Sea) (UNEP, 2009; Veiga et al., 2016), a figure which rises to $90 \%$ on the Israeli coastline (Alkalay et al., 2007; Pasternak et al., 2016). The lack of consistency in methodologies used to collect and measure marine litter make it difficult to analyse trends and to draw comparisons between the Regional Seas (UNEP, 2009). The main sources of marine litter in the Mediterranean are shoreline and recreational activities (52\%) and smoking-related activities (40\%) (UNEP, 2009). The last decade has brought public awareness of 
the high quantities and harmful effects on ecosystems and human health of microplastics in the global marine environment (Thompson, 2015). Preliminary results of a recent Israeli study indicate that abundances of microplastics in Israeli coastal waters are twice as high as the global average and up to 10 times higher than the average of microplastic particles found in the Western Mediterranean (Pasternak et al., 2016).

Marine litter has featured prominently on the European policy agenda in recent years, with one of the 11 descriptors of the EU Marine Strategy Framework Directive (MSFD, 2008/56/EC) dedicated specifically to marine litter. The MSFD requires EU Member States to implement measures to achieve or maintain Good Environmental Status (GEnS) in their marine waters by 2020, using existing regional cooperation structures to develop coordinated marine strategies in the four European regional seas. In the Mediterranean regional sea, the United Nations Environ- mental Program (UNEP) Mediterranean Action Plan (UNEP-MAP, 2008) has been adopted by all 22 (European, Asian and African) Mediterranean coastal states pursuant to the Barcelona Convention. (Cinnirella et al., 2014). The overriding objective of the Regional Plan on Marine Litter Management in the Mediterranean is to achieve GEnS in this regional sea (UNEPMAP, 2014). Although the MSFD applies to the Mediterranean Sea, the EU currently has jurisdiction over only $36 \%$ of this region. Challenges to governance of the Mediterranean Sea include the economic gap between the EU and non-EU coastal states (reflected in the different societal and ecological objectives in the region) and the need for alignment between the overlapping governance structures of the MSFD and MAP (Cinnirella et al., 2014).

Extensive research has already been carried out marine litter (e.g., Jambeck et al., 2015; Ryan, 2015). Most research has focused on impacts on the marine environment, particularly on marine wildlife (e.g., (Laist, 1997; Gregory, 2009; GEF, 2012; Bilkovic et al., 2014; Hardesty et al., 2014; Vegter et al., 2014; Gall and Thompson, 2015; Hardesty et al., 2015; Kühn et al., 2015). Recently, researchers have started to investigate the impacts of marine litter on people (Wyles et al., 2015; Butler et al., 2013) and the relationship of people, particularly users of the marine and coastal environment, to this litter (e.g., Slavin et al., 2012).

It is widely understood that without understanding the causes of marine litter, regulatory solutions will be greatly challenged (Chen, 2015) and that social norms are a driver of littering behaviour (RPA, 2013; Schultz et al., 2013). It has also been shown that, in addition to people's perceptions, littering behaviour is impacted by context specific factors such as the waste management capacity and infrastructure, along with the general cleanliness, of an area. Thus, understanding the relevant governance context is important to guide the formulation of effective policy measures to combat marine litter (RPA, 2013; EEA, 2015). In addition, the need to articulate the assumptions and values underpinning the design of policy approaches is gaining increasing recognition (Mee et al., 2008; Kooiman and Jentoft, 2009; Song et al., 2013; Mee et al., 2015; Victor, 2015; Voyer et al., 2015). This case study considers how the mental constructs underpinning artisanal fishermen's perceptions of marine litter interact with the relevant institutional context for the governance of the 'wicked' problem of marine litter. Artisanal fishermen ${ }^{1}$ are an important stakeholder group, related to the problem of marine litter, both as contributing to and being affected by it (see Nash, 1992; Al-Masroori et al., 2009). 
The purpose of the research is to provide policy guidance towards identifying possible points of intervention for waste planning and management approaches that could reduce marine litter in coastal towns.

${ }^{1}$ By artisanal fishermen, we refer to fishermen engaged in "traditional fisheries involving fishing households (as opposed to commercial companies, using relatively small amount of capital and energy, relatively small fishing vessels (if any), making short fishing trips, close to shore, mainly for local consumption" (FAO, 2005, n.p.).

\section{Quantitative and qualitative studies}

Although literature on perceptions of marine litter and awareness of its impacts is still sparse (e.g., Munari et al., 2016), the importance of research into such perceptions has increased in recent years (e.g., Eastman et al., 2013; Veiga et al., 2016). At the EU level, the MARLISCO (www. marlisco.eu) and CleanSea (www.cleansea-project.eu) projects have carried out extensive European-wide surveys on the perceptions of marine litter by the public and stakeholders (including commercial fishermen). However, these studies did not include indepth qualitative research on fishermen's perceptions of marine litter.

Earlier quantitative research investigated local artisanal fishers' perceptions of ghost fishing by traps in Oman by assessing the economic loss caused by such ghost fishing to the Omani fishery (Al-Masroori et al., 2009). Using social and beach surveys, Slavin et al. (2012) examined perceptions of marine litter from land-based sources by local beach and coastal user groups, to understand social drivers and physical pressures of marine debris in Tasmania, Australia. They found that certain populations were more likely to experience guilt feelings about littering and/or more likely to do something about the litter. These findings do not, however, indicate what social constructs or conditions drive litter problems. Bonaiuto et al. (1996) demonstrated that local and national identity processes play an important role in predicting the perception of a threat to the local environment. Thus, the more attached English secondary school students were to their local beach (the stronger their local identity), the less they perceived it as polluted, even if the EU assessment of cleanliness of the same beach indicated otherwise. Similarly, the more nationalistic the students were, the less they perceived their national beaches as polluted (Bonaiuto et al., 1996).

An exception to quantitative-study trends is qualitative research examining the impacts (but not perceptions) of marine litter on a small community of subsistence fishermen in Indonesia. The study focused on how marine litter impacted choice of fishing gear and fishing areas and, consequently, led to economic loss for the fishermen (Nash, 1992). Wallace (1990) used surveys to investigate the extent of the knowledge of commercial fishermen and recreational boaters about marine debris and entanglement. The study's results were limited, finding that the respondents perceived the causes of marine litter to originate from a group other than their own. Butler et al. (2013) looked specifically at the problem of ghost fishing gear with the intention of finding points of intervention to improve the situation. Wyles et al. (2015) used qualitative as well as quantitative methods in their study of the psychological impacts of effects 
of marine litter on people. From surveys administered to university undergraduates and members of the public, the authors found that marine litter can undermine the psychological benefits of coastal environments, with public-litter being rated more negatively than fishing litter.

Song et al. (2013) have pointed out that, while it is useful to understand attitudes and perceptions, these are underpinned by interacting and changing values, principles (or norms) and images (or worldviews), and that it is necessary to understand these underlying mental constructs to make a particular problem more governable. According to interactive governance theory, societal systems are made up of three components: a human-made "governing system", a natural-social "system to be governed", 2 and "governing interactions" which flow between the governing system and system to be governed (Kooiman and Bavinck, 2013). This theory examines underlying values, principles (norms) and images (worldviews) to improve understanding of the social "system to be governed". Interactive governance theory has been applied to fisheries governance (Jentoft, 2007; Jentoft and Chuenpagdee, 2009; Kooiman and Bavinck, 2013; Song et al., 2013) and, more recently, to the governance of marine protected areas (Voyer et al., 2015). In this paper, we apply interactive governance theory to help to identify the effectiveness of marine litter interventions in a particular socio-institutional and socio-cultural context, by considering the relevant values, norms and worldviews in the social "system to be governed". We understand 'values' as what people deeply believe and are ready to take action for (Kluckhohn, 1966; Zayadskaya and Welzel, 2013); 'norms' as implicit social codes of conduct (Checkland and Poulter, 2006); and 'worldview' as "a collection of attitudes, values, stories and expectations about the world around us, which inform our every thought and action.... A worldview is how a culture works out in individual practice" (Gray, 2011).

${ }^{2}$ Although we adopt the interactive governance theory concept of a "system to be governed" which is partnatural and part-social, we understand that, strictly speaking, only human activities can be governed, and not natural systems as such.

This research addresses a gap in the literature by providing qualitative insights into how artisanal fishermen perceive marine litter and its impact on their fishing activities and the marine environment ("system to be governed") in the context of the institutional structures ("governing system") which manage waste and aim to protect the surrounding environment. It problematizes (Foucault, 1984) ${ }^{3}$ the interactions between the governing system and the systems (natural and social) that are being governed in the fishing village area of Jisr-Az-Zarqa, a coastal town on the Mediterranean shores of Israel (Fig. 1) by considering how local worldviews, values and norms work together to influence governance processes and outcomes. The case study sits within the wider policy context of the joint commitments of the European Commission (via the MSFD) and UNEP (via the Mediterranean Action Plan) to achieve and/or maintain a clean, healthy and productive Mediterranean marine and coastal environment. It illustrates how differences in economic conditions and social priorities between the EU and non-EU political blocs in the Mediterranean region (Cinnirella et al., 2014) can impede the achievement of this shared goal. 
${ }^{3}$ By "problematize" we mean "to inquire into the terms of reference within which an issue is cast" (Bacchi, 2012: 1).

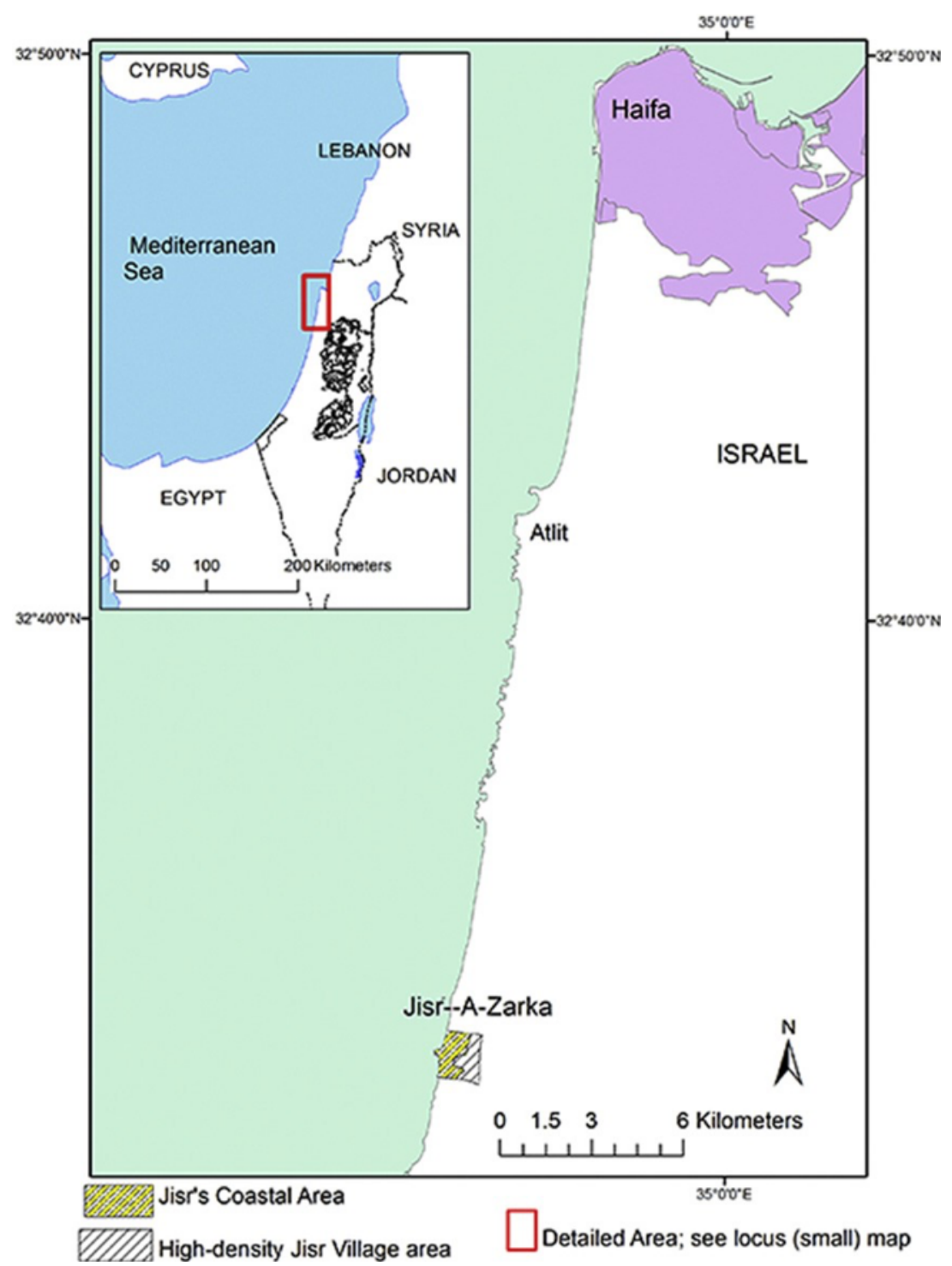

Figure 1. Locus map of the case study site.

\section{The case study}

In general, studies of marine litter in and around the Mediterranean Sea shores is relatively scarce (Munari et al., 2016) and particularly so with regard to fishermen. Along Israel's $190 \mathrm{~km}$ Mediterranean shoreline small fishing ports exist in several cities, although only Jisr has maintained a small artisanal fishery. It is also the only exclusively Arab town along Israel's Mediterranean shore and is relatively undeveloped. Its shore is composed of sandy beaches and shallow lagoons, some rocky headlands and kurkar ${ }^{4}$ cliffs. Sandy dunes cover the low backshore. Nearshore submerged areas consist of rocky reef habitats and abrasion platforms flanked by several small bays. Past studies in the Mediterranean have found that nearshore marine litter is concentrated in shallow coastal areas rather than in deeper waters 
(Koutsodendris et al., 2008) and in bays more so than in open areas (Galgani et al., 2015; UNEP, 2012) which makes Jisr an appropriate study site.

${ }^{4}$ Calcareous aeolianite (kurkar) interspersed with red loamy paleosol (hamra) units form ridges in the northern coastal plain of Israel. These ridges are rapidly eroding and suffering from over-development.

Although modern day Jisr was established in the early 1920s, the swamp-dwelling Bedouin ancestors of the town's residents, known as Arab Ghawarina, inhabited the area before the advent of the Ottoman Empire in 1516. The Arab Ghawarina may have been joined by Sudanese slaves brought from Egypt in the 19th century and by people fleeing their villages in the Jordan and Hula valleys because of blood feuds or land shortages (Frantzman, 2010; Rapoport, 2010; Frantzman and Kark, 2011). During the 1920s, the British Mandate licensed Baron de Rothschild's Palestine Jewish Colonization Organization (PICA) to drain the Kabara swamps (as part of the Zionist project) on condition that land was set aside for the local Arab Ghawarina.

Modern day Jisr was therefore established in the midst of Jewish concession land, granted to PICA in 1914 by the Ottoman Government (Frantzman, 2010; Frantzman and Kark, 2011). Jisr residents have long been ostracised by the town's Arab-Israeli neighbours because of its inferior nomadic (and possible slave) origins and because its residents were allowed to remain during the 1948 war (leading to inhabitants of Jisr being perceived as collaborators). As a poverty-stricken Arab town with a reputation for lawlessness, Jewish Israelis are reluctant to visit. This historical context continues to shape the worldviews of Jisr's residents today. Modern day Jisr is economically distressed and densely populated. In 2014, the town's population consisted of 13,400 residents, $99 \%$ of whom are Muslim. It is one of Israel's poorest communities, with town residents falling in the lowest out of ten socio-economic clusters (CBS, 2013a, 2013b). The clusters are determined using 16 socio-economic variables as parameters, including those related to income and standard of living. $40 \%$ of Jisr's working age population receive unemployment benefits and $60 \%$ of wage-earners receive sub-minimum pay. The average monthly salary per capita is approximately USD350 per month (CBS, 2013c). Only 4 out of 252 local authorities in Israel are ranked in the lowest socio-economic cluster (CBS, 2013b).

Jisr is allotted very limited space by the state $(1.6 \mathrm{~km} 2)$ in relation to its population size; it is environmentally neglected (with large amounts of solid waste in public areas, lack of access for waste collection vehicles and vandalism of waste collection bins), tax collection rates are low, as are matriculation examination completion rates (26.6\%). Unemployment rates are high (25\%) and almost 50\% of the population is under 18 (CBS, 2013a, 2013c; Arlozorov, 2016). However, the town is well-located between two major cities (Tel-Aviv and Haifa) and adjacent to the ancient Roman-era port of Caesarea, a major tourist attraction. A nature reserve (established in 2003) adjoins the town. In 2014, local entrepreneurs opened a small guesthouse-cum-social business above a café in the center of the town, and other initiatives are underway to bring more tourists to the village, including development of its artisanal fishing village for tourism (Kamisher, 2015; Arlozorov, 2016). 
The abundance of marine litter on Israeli beaches has recently been shown to be lower than the global average. However, this may be due to the regular cleaning of most of the beaches surveyed for that study (Alkalay et al., 2007; Pasternak et al., 2016). Since early 2016, a regional level institution (Haifa District Waste Management Division of the Ministry of Environmental Protection) has been tasked with leading an overhaul of the entire waste management system in Jisr. A draft general development plan (PCMP, n.d.) envisions a town that provides its inhabitants with proper living standards, livelihoods, a high standard of public services and enjoyment of its unique seashore location. A draft National Park and Nature Reserve plan (IPA, 2009) envisages the Israel Nature Parks Authority (INPA) taking the lead in developing, and improving the appearance of, the fishing village in an environmentally sensitive way. This will make the regulatory environment present and visible in Jisr's fishing village in a more formal manner than has previously been the norm. The INPA has already taken steps in this direction by employing three local fishermen, since May 2016, to clean the part of the beach under the jurisdiction of the INPA, which includes the beach in the fishing village.

The research was carried out taking into account the historical, socio-economic, and cultural context outlined above and guided by two research questions:

1. What are local fishermen's perceptions of marine litter on Jisr's beaches and in its sea, and what is their awareness of its impacts?

2. What are the main challenges to the prevention of near-shore marine litter in Jisr?

3. Methods

\subsection{Qualitative research approach}

A qualitative research approach was used which involved conducting 6 in-depth face-to-face semi-structured interviews with local fishermen to explore their awareness of marine litter and its impacts; and 5 in-depth face-to-face unstructured interviews with members of Jisr local council and INPA, between April and June 2016, to gain an understanding of the social, historical, political and cultural aspects of waste management in Jisr. Preliminary unstructured interviews were conducted in February 2016 with nine people living and/or working in Jisr in order to gain an initial understanding of the socio-cultural fabric of the village. These preliminary interviews were treated as field notes and provided one of the sources for triangulation of data during the analysis of the subsequent in-depth interviews (see below). The remainder of this section discusses in detail the process used for conducting and analysing the in-depth interviews with the eleven interviewees (Table 1).

\subsection{In-depth interviews with fishermen}

Six fishermen were recruited for interview. The main recruitment method used involved the interviewer and translator having an informal conversation with a group of fishermen sitting outside their beach huts, sharing food and tea with the group, and then inviting other members of the group to take part in an interview. Fishermen were also recruited by using a snowballing sampling technique whereby initial respondents suggested other fishermen to approach 
(Morgan, 2008). Therefore, interviewee selection was not random, but depended on the availability of individual fishermen and their willingness to be interviewed. Six semi-structured, face-to-face interviews were conducted with the fishermen. In accordance with guidance for intercultural research (see Van de Vijver and Leung, 1997), the interviews were conducted in Arabic, the fishermen's local language, with a native Arabic speaker performing simultaneous translation for the interviewer. To minimize any data distortion issues, before and after each interview, the interviewer reminded the translator of the importance of translating exactly what was being said, rather clarifying before translating.

The interview questions addressed the following themes:

- Working background as a fisherman;

- Perceptions of litter at sea and on the beach;

- Perceptions of the impacts of marine litter on fishermen and on the environment;

- Awareness of the link between marine litter and fishermen's behaviour;

- Perceptions of marine litter interventions relevant to Jisr.

The semi-structured interviews enabled the interviewer to adopt an open and flexible question order. Interview questions were not asked in the same order, or even in the same way. Rather, the interviewer phrased the questions in a way that best reached each fisherman and which encouraged the fisherman to engage in free flowing conversation about issues that they considered important in relation to marine litter and waste management. This ensured that the field of discussion was not prematurely restricted (see Bryman, 2008).

Table 1. Interviewee codenames. $\mathrm{F}=$ Fisherman; NP = INPA employee; $L C=$ local council employee. There are two overlaps: one local fisherman is now employed by the INPA, and one INPA employee used to be a local fisherman. To maintain anonymity, the table does not identify these overlaps.

\begin{tabular}{|c|c|c|}
\hline Interviewees & Interview location & Interview length \\
\hline \multicolumn{3}{|l|}{ Fishermen } \\
\hline F1 & Fishing village & $2: 00$ \\
\hline F2 & Fishing village & $2: 40$ \\
\hline F3 & Jisr town & $1: 10$ \\
\hline F4 & Fishing village & $1: 00$ \\
\hline F5 & Fishing village & $1: 15$ \\
\hline F6 & Fishing village & 1:05 \\
\hline \multicolumn{3}{|c|}{ Institutional interviewees } \\
\hline NP1 & Fishing village & $1: 00$ \\
\hline NP2 & Taninim Nature Reserve & $1: 00$ \\
\hline LC1 & Local council offices & $1: 45$ \\
\hline LC2 & Local council offices & $1: 30$ \\
\hline LC3 & Local council offices & $0: 50$ \\
\hline
\end{tabular}




\subsection{In-depth interviews with representatives of Jisr local council and the INPA}

Five unstructured interviews were conducted with three local council representatives and two locally-based representatives of the INPA in order to gain a better understanding of the institutional context for the fishermen's perceptions. Interviewees were recruited on the basis of their direct connection and engagement with the fishermen and/or responsibility for the waste management system in Jisr.

\subsection{Informed consent and interview recording}

Informed consent to take part in the study was obtained from each interviewee. Each interviewee was asked to sign the consent form at the end of the interview and was given a copy of the form to keep. In this way, obtaining consent was treated as a process rather than a single event (Ritchie et al., 2014). The interviewer made detailed contemporaneous verbatim notes of her questions and the interviewee's responses during each interview. It was considered that audio-recording the inter- views could be intimidating for interviewees, and particularly for the fishermen, as the interviewer had no prior working relationship with them. Each interview conducted was used to inform and refine the interviewer's approach to the next interview. Interviews varied in length from 60 to $160 \mathrm{~min}$ for the fishermen and from 50 to 90 min for the institutional interviews.

\subsection{Coding and analysis}

Data analysis involved coding interview transcripts (Bryman, 2008) using NVivo 10 qualitative data analysis software. The aim was to identify key themes which provided insights into artisanal fishermen's perceptions of marine litter in order to inspire ideas for effective planning interventions to reduce marine litter. Data were triangulated from different sources wherever possible. This meant that data from the interviewer's observations (fieldnotes), interviews and other archival data (i.e., relevant news reports, the literature and the nine preliminary unstructured interviews) were analysed to see if they converged in what they were saying (Yin, 1994; Burawoy, 1998; Creswell, 1998).

Interviews were transcribed personally by the interviewer within two days of conducting each interview and were analysed in NVivo using an iterative process of coding, sorting and categorising. During transcription and a detailed read-through of the interviews, initial codes (free nodes) emerged. Fifty-three initial codes, shaped by the overall themes addressed and by the detailed issues, ideas and perspectives in the interview data, were treated as broad ideas that emerged from the interviews (such as a fear of improvement leading to dispossession). Using NVivo, these initial codes were subsequently merged into hierarchies (tree nodes) by reviewing the codes (and related data) and grouping similar codes together (see Bryman, 2008). Thirteen thematic headings resulted. The majority of codes were grouped under:

- challenges to preventing marine litter;

- motivating factors to clean or prevent marine litter; and 
- perceptions of marine litter.

In addition the interviews were analysed for:

- values;

- social norms;

- power dynamics; and

- worldviews.

\section{Findings and discussion}

In this section, it was deliberately chosen to foreground the research participants' voices by including direct quotations in the body of the narrative, as opposed to placing them in tables. This reflects the value accorded to these voices and the importance of the contextualized nature of this research.

\subsection{Working background as a fisherman}

Only one of the fisherman interviewed made his living entirely from the sea - through fishing and running his seafood restaurant on the beach. The other fishermen either had other jobs or depended on social welfare. All of the fishermen interviewed used gill nets and two also used spear guns. Although five fishermen said they used long lines, three fishermen did not use them frequently anymore due to the decline in the stocks they used to catch with longlines. Each fisherman interviewed described himself as coming from a fishing family, and started fishing as a boy with his father and grandfather. An emotional connection to the sea and to fishing was evident from all the fishermen interviewed.

If you asked me to choose between my wife or the sea, I'd pick the sea, even though I love my wife very much! [F1]

The sea is in my blood. Even if it means paying tons of money, I wouldn't leave it. [F2]

If I get out of the sea, I don't live. It's like I'm part of the fish there. [F3]

\subsection{Fishermen's perceptions of litter at sea}

The fishermen had mixed and sometimes contradictory perceptions of the cleanliness of the sea around Jisr.

Two fishermen perceived it as "the cleanest sea on the coast" (F2), yet both also mentioned waste water pollution as a problem.

There's a lot of pollution in the water... The industrial waste and the waste waters that get dumped in the sea. 
From Atlit to Netanya [the central coastal region] this is the only sea shore where the water is very clean so that's why people come here to buy fish. The fish smells like chip oil in Haifa and

Ashdod. We don't have big ships a lot here. [F1]

Two fishermen perceived the sea as not containing a lot of litter.

There's always nylon [plastic bags] but not a lot. Sometimes we find a lot, sometimes less, but every time at least one. [F3]

[T]he sea is clean so we don't find a lot of litter, not always. [F4]

Two fishermen perceived the sea as littered with plastic.

I find plastic cups a lot in the nets and a lot of plastic containers. [F5]

Yes, plastic, nylon [plastic bags], it's something normal that we're used to. We fish nylon more than fish. [F6]

When asked about catching litter at sea, five fishermen mentioned plastic litter, although three said that they also catch a lot of seaweed in their nets. Only one fisherman said he never caught any litter.

Today there's less plastic and nylon [plastic bags] but we still catch a lot of litter in the nets.... 40 years ago it didn't exist. 20 years ago we began seeing it. Right now it's a bit less than 20 years ago but it's still there. We sometimes find big bags filled with litter, closed and floating on top of the water. We think the big ships throw them. [F1]

The only thing we catch with the nets is seaweed, we don't see plastic or anything like that. [F2]

\subsection{Fishermen's perceptions of litter on the beach}

Like their perceptions of the sea, the fishermen's perceptions of beach cleanliness tended to be contradictory. Almost all of fishermen recognised the problem of litter left behind by beachgoers, yet they perceived the beach as relatively clean because it is cleaned by the local council or by the fishermen themselves, and because it was dirtier in the past when nobody cleaned it.

We have a clean beach only in the swim season - they bring people to clean every day. We have a lot of bins they put during that season and they always flip the sand so there's always people working, the bins being cleaned. [F3]

I give my children bags and we clean the beach.... There's been a bit of a change lately with people coming from the outside as I'm pressuring them and telling them not to sit here if they 
throw their trash around. At the moment, from my point of view, this place is the cleanest. 5 years ago there was a lot of litter. [F2]

Although most of the fishermen thought that the beach was now cleaner than a few years previously (due to beach cleaning rather than due to lack of littering behaviour), one fisherman felt that the situation had got worse.

Where I sit over there [pointing to his hut], I tell them [beachgoers] to pick up their litter but I've been noticing it this past 10 years, really noticing it.... They throw everything. [F5] In terms of values, it seems that a clean beach and sea is desirable, and a source of pride, amongst Jisr's fishermen. However, the beach is perceived as clean if it is cleaned regularly, as opposed to not littered in the first place. The locus of perception is on whether litter is being managed rather than prevented. This suggests a worldview which is accepting of end-of-pipe litter interventions, but which may not necessarily understand the need for preventative interventions. Similarly, the perception of the sea as clean suggests a worldview which does not understand that beach litter is a source of litter in the sea. Designing preventative management measures that go beyond improvement in waste management practices has been identified as a key challenge in addressing marine litter (UNEP, 2009; DG ENV, 2011; STAP, 2011).

The fishermen's strong sense of belonging to the fishing village seems to have had some influence in changing, amongst the fishermen, a well-established norm in Arab society. While private spaces (homes) tend to be very clean in Jisr, the acceptability of littering public spaces in Arab society has been recognised in the literature (see Arafat et al., 2007; Al-Khatib, 2009; AlKhatib et al., 2009) and by the fishermen interviewed.

It's an Arabic thing. We don't clean the place we sit in. ... as Arabs, we leave all our stuff in the place and don't clean it after us.... Sometimes we give them bags to collect their waste and they leave them there in the spot where they eat. [F1]

It's a big problem between Arabs. You tell people that are littering to stop as it's not nice and it's harmful and shameful and they don't listen and they look at me weirdly and make fun of me and say I'm making a fuss out of nothing. [F2]

By encouraging beachgoers not to litter, and by cleaning the beach themselves, Jisr's fishermen seem to apply the norm of cleanliness for private spaces to the public beach in front of their huts, suggesting a sense of ownership (and stewardship) for 'their' beach. The beachgoers (predominantly Arab, since this is the only Arab beach in Israel), in contrast, appear to conform to the public littering norm, providing further empirical evidence that social norms are a driver of littering behaviour (see RPA, 2013; Schultz et al., 2013).

\subsection{Fishermen's perceptions of the negative impacts of marine litter on fishermen and} on the environment 
Three fishermen said that litter in their nets affected their fishing by frightening the fish away or tearing their nets.

It [litter] just does bad for everybody. It frightens the fish away. It gets caught in everyone's nets. It takes a lot of time to clean it. It's just bad for everything. [F3]

At a certain time we find litter, we find nylon [plastic bags]. But mostly it's seaweed. [F4]

Overall, the fishermen were far more concerned about how the decline in local fish stocks is affecting them. All of them identified the fishing of juveniles by large commercial fishing boats as one of the main reasons for this decline.

The trawlers come and grab all the big fish and kill the small fish. [F6]

There was some awareness of the impact of marine litter on the environment.

I think all these things we find in the sea, all the plastic, I think they poison the fish as they try to eat the plastic. [F1]

However, there was a distinct lack of knowledge as to the extent of this impact. For example, one fisherman believed that lost fishing gear was transformed into rocks by the sea salt over time, another believed that fish don't eat plastic (although he also pointed out that plastic doesn't dissolve "for a long, long time") and two of the fishermen said they didn't really know.

\subsection{Awareness of the link between marine litter and fishermen's behaviour}

Almost all of the fishermen acknowledged losing and catching nets at sea.

Yeah, everything that gets lost and that I lose as well, some others catch it, it gets gathered in the nets. [F1]

One fisherman pointed out that the nets were usually washed up on shore and the fishermen always dived for and recovered the lead weights.

When the sea rises, the floats rip the nets off and they go onshore and the rest is diving inside in the sea. Bullets [lead weights] cost 400NIS [USD100] each so it's better for me to dive and get them. [F4]

Three other fishermen described rescuing ADLFG at sea and bringing it back to shore, either for collection by its owner or for mending and reuse by the collector.

The same fisherman who said he never found litter at sea did not perceive lost fishing gear as a litter problem, because the fishermen recover lost gear and because the sea self-cleans. 
Nothing that gets broken from here gets into the sea because the sea cleans itself. In the sea everything diminishes. If there are hooks, in the sea, after a few years there's nothing... The

metal doesn't survive the salt. The nets turn into rocks. The salt builds rocks. The nets catch the salt and starts shaping the rock. After years it turns into rocks. [F2]

It is clear that the fishermen did not perceive their abandoned, lost or discarded fishing gear (ADLFG) as contributing to litter on the beach or in the sea. This is in contrast to their perceptions of non-fishing-related items as litter (sections 5.2-5.4) This distinction can be explained as the fishermen value their fishing gear highly and make every effort to recover any gear found at sea. It also reflects a finding made in a recent national assessment of ADLFG in Israel where almost all of the 50 respondents said they tried to prevent gear loss and recovered nets when caught (EcoOcean, 2015).

Although five fishermen pointed to the lack of bins on the fishing beach as a problem, it was not clear whether they were concerned with waste on the beach left by visitors, their own waste or a mixture of both. All of the fishermen interviewed identified the main sources of beach litter as coming from visitors (mainly outsiders) to the beach. As several fishermen said they provided bags to visitors for their litter, and cleaned up after them, it was clear that they perceived a link between other people's behaviour and marine litter. It is recognised that behaviour changing schemes and local participation in designing solutions are fundamental for policy to effectively address marine litter at its root (Liffmann et al., 1997; Hartley et al., 2015). Although it is likely that the fishermen also contribute to beach litter (as it is not unusual to attribute socially undesirable behaviour to others (Schultz et al., 2008; Bator et al., 2011)), the fishermen's selfmotivated cleaning of the beach in front of their huts provides an opportune entry point for an effective marine litter intervention.

\subsection{Perceptions of marine litter interventions relevant to Jisr}

Two fisherman referred to the need for education to address the problem of litter on the beach. One simply said that "they should teach the kids at school that it's not good to litter" [F5]. The second insisted that school, home and religious environments were responsible for instilling anti-littering norms in young people.

All the lectures they do in schools and other places here, it should be mainly on trash...and how it pollutes the place. Even in the mosque, I think the elders should talk about it. Instead of talking about meaningless stuff why not talk about trash and cleaning the town?... I believe that every house has someone who goes to pray in it and that people would listen. There's an Arabic saying "cleaning comes from believing" [من للنظفاة يلامنا| It's a religious thing. It would actually push people to clean when they hear it from a religious man. [F1]

This provides another potential entry point for an intervention aimed at altering the acceptability of the public littering norm. It is a variation on Sidani's (2005) observation (in relation to the lack of female participation in the public arena in Arab society) that prevailing 
cultural norms (which do not always originate from religion) can be reinforced by religious edicts.

One fisherman pointed to the success of an economic intervention in reducing beach litter while observing that past beach cleans by the INPA only had a temporary effect.

Today there isn't much, especially plastic, because plastic bottles, they pay if you recycle them, so people collect and sell them instead of throwing them away. [F3]

Everything came back and nobody cleaned it afterwards [F4]

Two fishermen pointed out that the bins put on the beach in the past by the council had not been effective to reduce beach litter, either because they were not used or were burnt (allegedly by the fishermen).

The mayor before this one, he put trash cans on the beach every $50 \mathrm{~m}$ but it didn't work. People still threw garbage and left their stuff behind. [F1]

There are usually no bins on, or near, the beach (other than on the bathing beach during the summer swimming season (Figs. 2 and 3). The initial fishermen I interviewed complained that they don't have a big skip nearby, and alleged that the council has refused to provide them with one. However, when a skip appeared at the beginning of May 2016 (put there by the INPA), it was burnt two weeks later (Fig. 4), allegedly by one of the fishermen.

As noted above, the fishermen want the beach to be clean, yet they try to prevent the three local fishermen employed by the INPA since May 2016 from cleaning the beach in front of the fishermen's huts (Fig. 2).

During the course of the in-depth interviews, it became clear that, until the relationships between local people and the various governing institutions are transformed, there is little hope for citizen cooperation in reducing marine litter in Jisr on a long-term basis. This is due to a prevailing worldview (and fear) within the fishing village that its improvement by an outside authority (in this case, the INPA) will inevitably lead to displacement and dispossession of the local fishermen. Understanding the fishermen's fear of the INPA requires an understanding of the wider policy context (governing system) which involves measures to improve the socioeconomic status of the village, reform its waste management system and protect its coastal and marine environment. The problem of marine litter in Jisr is nested within these proposed changes since they involve improvement of the village's aesthetic appearance. 


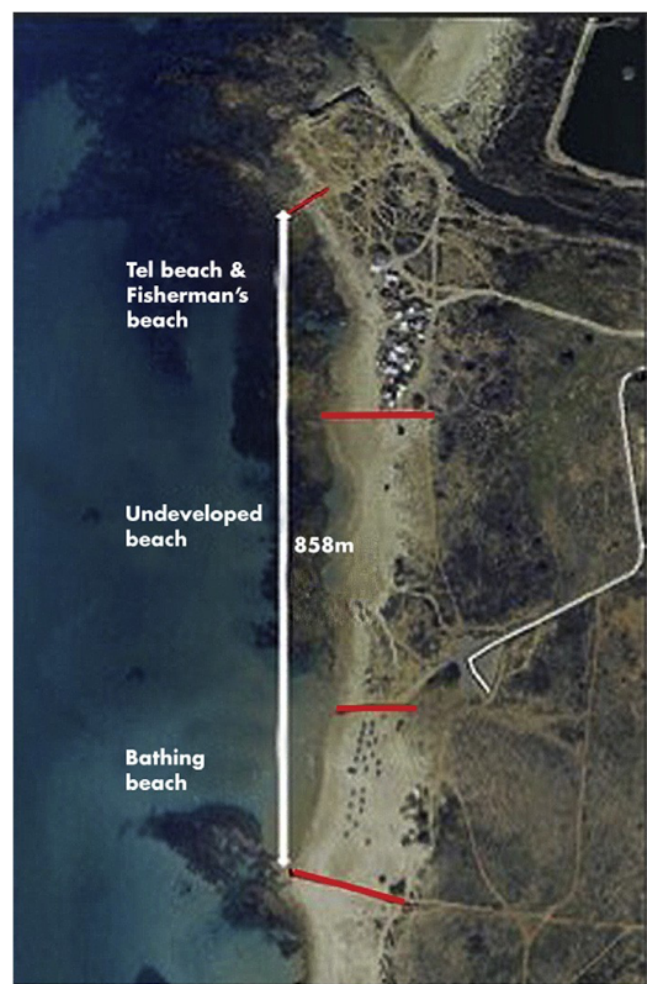

Figure 2. The beach at Jisr-az-Zarqa divided into 3 sections: the tel (hill) and fishermen's beach, the undeveloped beach and the bathing beach. Jisr's local council is responsible for the latter. The INPA is now responsible for the first two sections of the beach. Adapted from www.govmap.gov.il

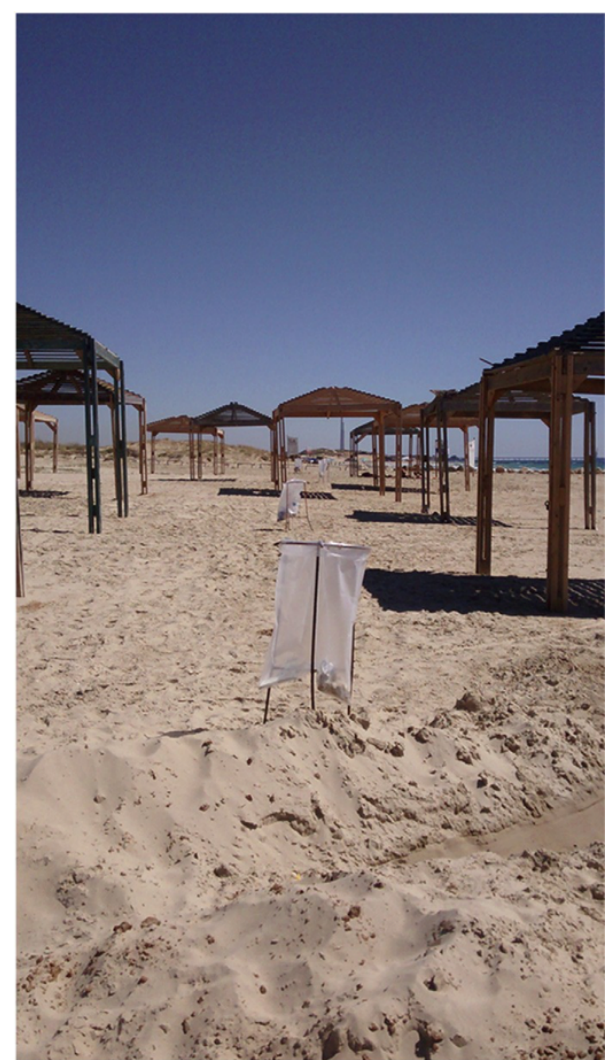

Figure 3. New bins on the bathing beach, June 2016, Jisr-az-Zarqa 

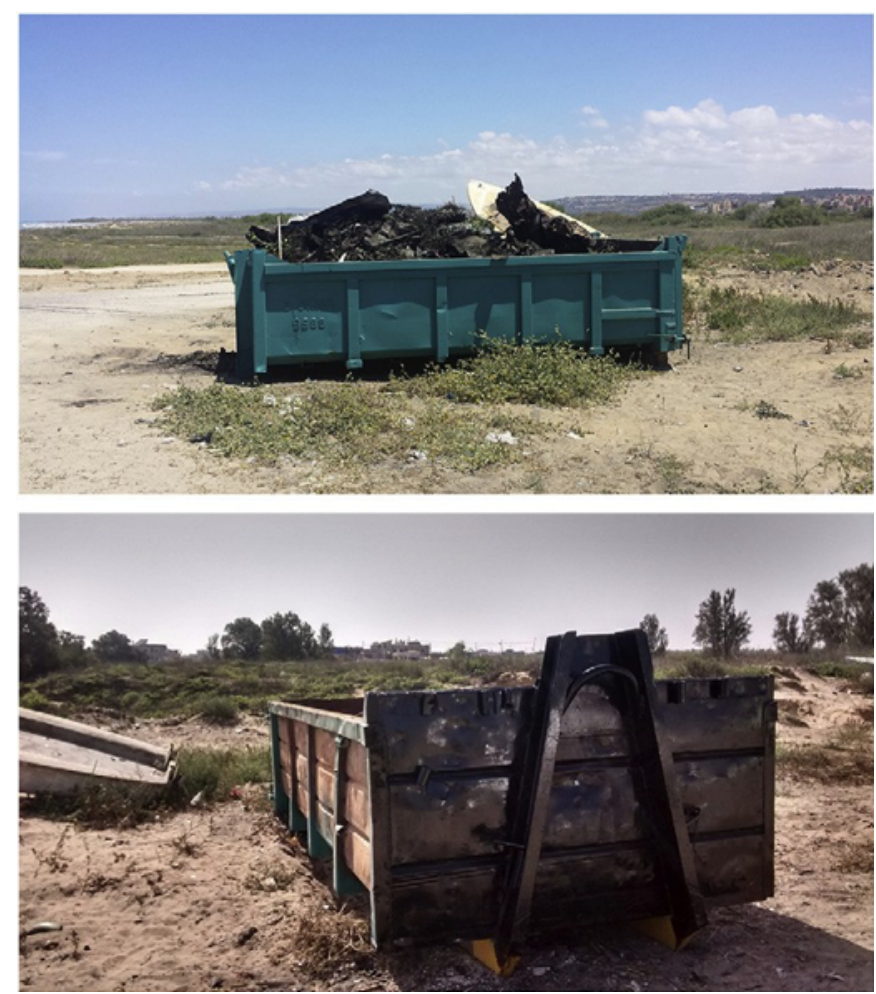

Figure 4. INPA skip beside the fishing village - before and after.
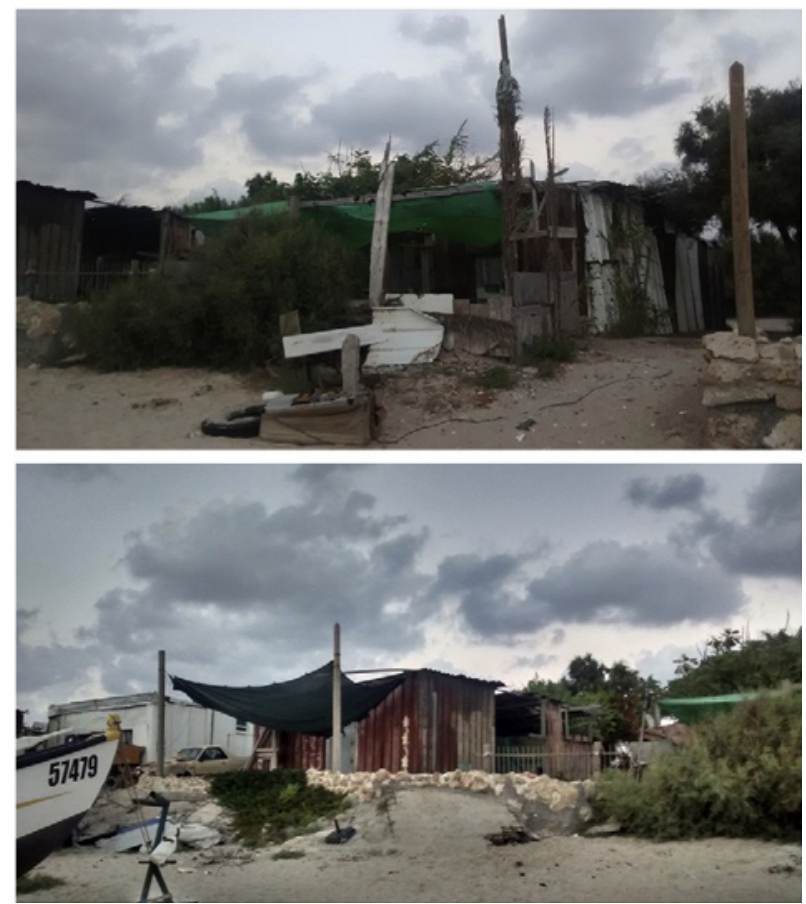

Figure 5. Corrugated iron fishing huts, Jisr-az-Zarqa.

5.7. Interactions between the governing system and system to be governed

A draft National Park and Nature Reserve plan (the 'Plan', IPA, 2009) to improve Jisr's fishing village will make the regulatory environment present and visible in the fishing village in a more 
formal manner than has previously been the norm. The Plan envisages the creation of a national marine park, the deepening of the harbour, the construction of a breakwater and coastal boardwalk, the demolition of the existing corrugated iron fishing huts (Fig. 5) and their replacement with a series of small structures designed to house restaurants, storage sheds, a fish processing facility and government offices. The proposed changes under the Plan have triggered the fishermen's fear of displacement and dispossession.

The plan that has been most recently put together by the government... is called Gan Leumi Jisr (Jisr National Park).... This is why the fishermen came here last week and this is what they were angry about. They want the harbour to stay the same and they are against improving it because what they believe is that design and planning and changing the place will be followed by the government taking control and taking them out. [LC2]

Five of the six fishermen interviewed insisted that any change to the village should come from the local council (the fisherman who disagreed is employed by the INPA). However, the local council is beset with internal power struggles and management problems.

There are power struggles involved in enforcing the management programme. I don't give a damn about saying this on the record.... At the moment, whoever is responsible cleans the [bathing] beach whenever they feel like it. When they don't feel like it they don't clean it. [LC1]

Hence, the State has assigned to the INPA the lead role (in terms of funding and management power) in the development and aesthetic improvement of the fishing village. Although reform of the waste management system in Jisr has been underway since early 2016, the funding is administered and tightly controlled by the regional level Haifa District Waste Management Division of the Ministry of Environmental Protection. The allocation and control of funding is an indication of where power is held. Jisr's local council is thus disempowered in terms of finances and capabilities. Several fishermen criticised its failure to spend money on the fishing village in the past. Even a council representative acknowledged that calling for more power at a local institutional level was problematic.

...[T]he places that are under our responsibility right now are not managed well. So there's a strong argument not to give the local council any more power. [LC1]

When viewed through the lens of power dynamics, the fishermen's call for the local council to be in charge of funding to improve their village (even though they have a proven track record of failing in this regard) can be understood as a call for the locus of power to remain at an institutional level which is closest to the fishermen. This suggests that the change really feared by the fishermen is not the outer appearance of the village (as they talked about making changes which, in some cases, mirrored the changes proposed in the Plan), but the increased regulatory footprint of the INPA (and other institutions) in the village via the regulatory power and restrictions that come with making the fishing village a national park. 
The interviewees did not all share the same narrative. Some local fishermen and institutional representatives seemed to accept that the INPA genuinely wants to clean and improve the fishing village, but that the result of this will be to displace the fishermen (intentionally or unintentionally). However, some (often in the same interview) perceived the proposed improvement as a smokescreen to cover an intentional displacement of the fishermen. Underlying this seems to be a polarised narrative of "If the place is nice and clean, the Jews will want it and take it for themselves; if the place is dirty, the Jews won't want to be there and will leave it to the Arabs". This culturally-rooted suspicion and distrust of the INPA operates as a significant barrier to behaviour change which could reduce marine litter on the beaches under the control of the INPA.

The Shmoorot HaTeva [INPA] people came here and offered to make this a better place and give us a job but we know as Arabs that they would not be coming to help us if they wouldn't be benefitting from it themselves. It's something deep within.... At first they come with all ideas and plans and in the end it's just piles of lies. [F2]

Viewed in this socio-institutional context, tackling marine litter in Jisr can be described as a 'wicked' problem. Such problems are difficult to define and delineate from other problems, they have no right or wrong solution which can be determined scientifically, it is not clear when they are solved, they need to be dealt with by a collective process which is experiential, interactive and deliberative, they entail more than one legitimate perspective and the problem definition can change and evolve with suggested solutions (Rittel and Webber, 1973; Jentoft and Chuenpagdee, 2009; Kwakkel et al., 2016). One of the principal sources of wickedness is the prevailing worldview within the fishing village that the changes proposed by the Plan will lead to a loss of control over the sea and beach for the local fishermen. Any government-driven improvement to the village (including interventions which reduce marine litter) have the potential to trigger this fear and result in a lack of cooperation from the fishermen (for example, by burning bins). The prevailing socio-cultural context of Arab society within Israel (one of exclusion) unfortunately supports this worldview.

\section{Assessing the effectiveness of proposed marine litter management options}

Lessons learnt from this case study are the basis of a 6-stage checklist presented in Fig. 6 to assess the potential effectiveness of marine litter interventions in a local context (elaborated in sections 6.1-6.6). The 6 inter-related stages in the checklist are aimed at guiding planners and policy-makers towards understanding whether a proposed intervention is likely to work, or not, in a particular local context. The answers to the questions have the potential to shed light on potential points of conflict and to thereby guide planners and policy-makers in a more nuanced approach to marine litter interventions that is sensitive to the relevant local context. The key message is that it is necessary to think about the relationship between the institutional context and local values and worldviews in order to effectively target funding and to maximise opportunities for successful management interventions. 


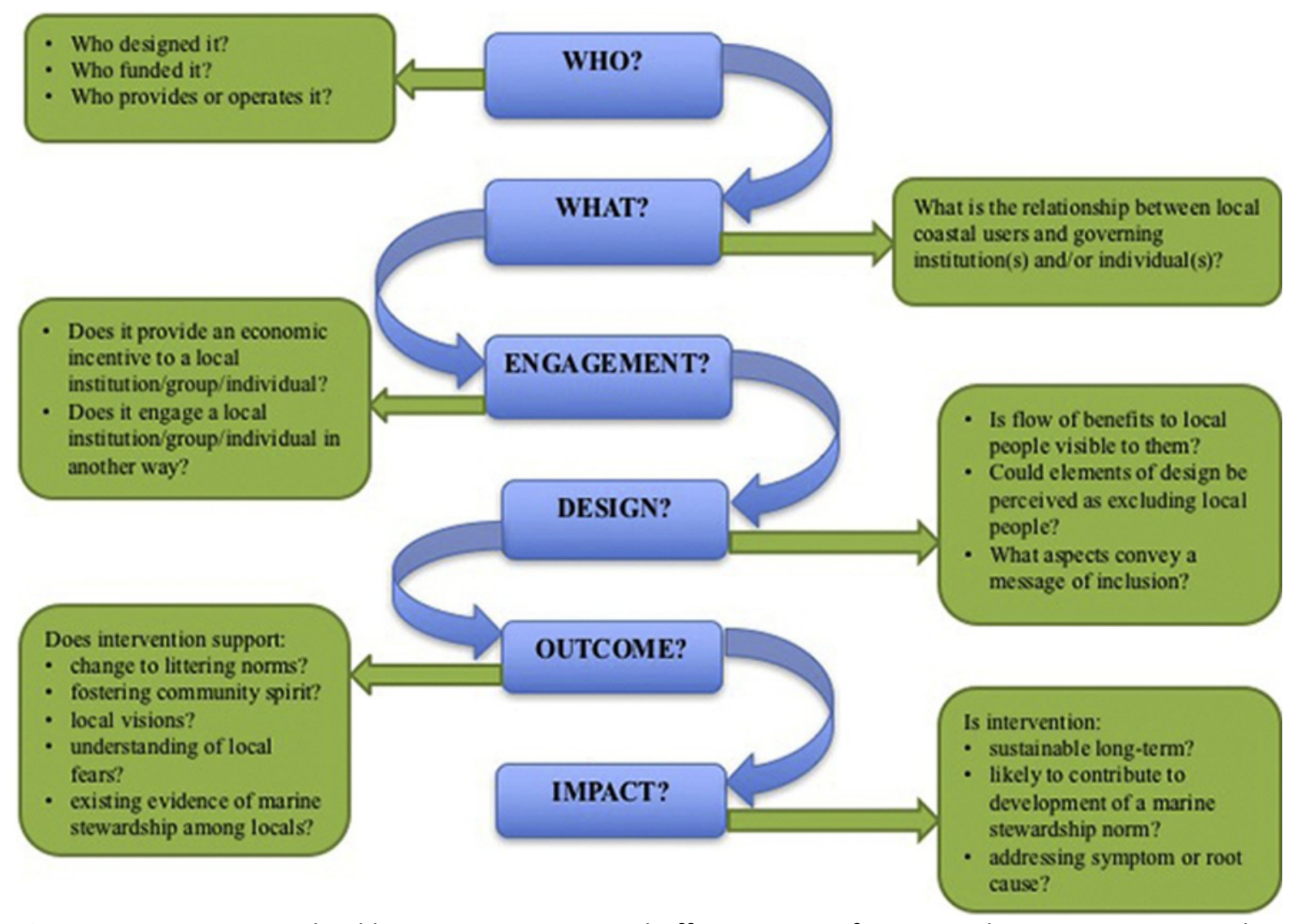

Figure 6. Intervention checklist to assess potential effectiveness of a marine litter intervention. The answers to the questions have the potential to highlight potential conflicts and to guide planners and policy-makers in a more nuanced approach to marine litter interventions that is sensitive to the relevant local context.

\subsection{Control and operationalisation of intervention}

The burning of the INPA skip (allegedly by one or more fishermen) and the fishermen's antipathy towards the cleaning of the beach in front of their hut by INPA employees indicate that, in Jisr, it is important to ask who should or should not be responsible for cleaning the beach or placing bins on the beach in order to make that intervention most effective. Reflecting on who controls and operates the intervention directs attention towards the relationships which can determine the success or failure of the intervention.

\subsection{Relationships between local coastal users and governing institutions}

The historically-rooted suspicion of the fishermen towards the INPA, and, more generally, towards changes instigated by outsiders, suggest that it is advisable to think about the relationships between the relevant governance structures and local coastal users. Trustbuilding initiatives may be needed to pave the way for a proposed intervention. In the case of extreme cases of distrust or it may be more effective to task a different institution with the control and operationalisation of the intervention. 


\subsection{Engagement with local context}

The fishermen in Jisr were not involved in the conceptualisation or drafting of the INPA Plan. This was a missed opportunity, as the details of the Plan reflect to a certain extent the fishermen's own visions for the village. In addition, the fishermen's sense of ownership of the beach in front of their huts appears to be encouraging a marine stewardship norm as they are independently dealing with litter left by beach-goers. This illustrates that engaging with the local context from the outset can reveal synergies which in turn can feed into improving relationships between local coastal users and the relevant governing institutions. Engagement must be meaningful, such as connecting to and building on an existing local initiative or idea.

\subsection{Design of intervention}

The Taninim Nature Reserve was created, in 2003, on land which was previously part of Jisr's town. As the new coastal road (Route 2 ) bypasses Jisr, the town does not benefit economically or socially from visitors to the Taninim Nature Reserve which is accessed via Route 2 . Although the town residents can access the nature reserve, by foot, free of charge, residents resent the failure to design access to the reserve in a way which would bring a much-needed economic stimulus to the town. This calls for careful consideration to be given to the message conveyed by design of an intervention to ensure its effectiveness is not undermined by a message of alienation and exclusion. Meaningful engagement with the local context can point planners and policy-makers in the right direction in this regard.

\subsection{Likely outcome of intervention}

The changes proposed by the INPA Plan are intended to improve the appearance of the fishing village (including the reduction of beach litter). However, the absence of meaningful engagement with local coastal users and lack of consideration of the power structures solidified by the Plan mean that its outcome is likely to bring about a forced change which will contribute to a deterioration in the relationships between many of the fishermen and the INPA. Interrogating the likely outcome of a proposed intervention can guide planners and policymakers towards the previous stages of the checklist that need attention.

\subsection{Likely impact of intervention}

The burning of the INPA skip in the fishermen's village is an example of an intervention that was unsustainable in the long-term, not least because it was underpinned by a problematic relationship between the INPA and many of the fishermen. It is worth considering whether engaging with women in Jisr (particularly the women of fishing families) could contribute to the longer-term sustainability of a marine litter intervention. It is noteworthy that the 11 in-depth interviewees in the case study did not include women's voices as Jisr does not have any fisherwomen and the institutional positions in the INPA and the local council relevant to this research are held by men. This reflects the wider lack of documentation of the role of women in 
the marine environment (Frangoudes et al., 2013). Although the last few decades have seen fundamental changes to prevailing cultural norms in Arab society whereby the public sphere is traditionally assigned to men (Sidani, 2005), in Jisr, public spaces are considered the domain of the men, while women (even those who work outside the home) are considered responsible for child-rearing and the cleanliness of the home. For example, the many cafes in Jisr are frequented by men, and there is no public space dedicated to women. Future research in Jisr needs to include women's voices, engage them in leadership roles and harness their influence on the younger generation in order to bring about a wider change in the public littering norm.

Questioning the impact of an intervention requires big-picture thinking which considers the complexity of the relevant social-ecological system. In the case of Jisr, the difficult socioeconomic context and related values and worldviews are impacting efforts to sustainably manage the marine and coastal environment. At the same time, it shines a light on the issues which need to be considered in order to increase opportunities for successful marine litter management interventions. It also reflects the finding of the recently completed CleanSea project, that addressing the roots of the marine litter problem lies in social and political innovations, participatory governance and paying better attention to human values systems. Only by doing this can we hope to bring about transformations in our systems in which the driving forces behind marine litter are embedded (CleanSea, 2015).

\section{Conclusion}

Until the relationships between local people and the various governing institutions are transformed, there is little hope for citizen cooperation in reducing marine litter in Jisr on a long-term basis. The proposed intervention checklist has the potential to provide a path towards improving such relationships, by highlighting potential conflicts and encouraging an approach that is more sensitive to the local context. From a broader perspective, this case study provides empirical evidence that marine litter is a highly contextualized problem, the governance of which is shaped by subjective value judgements and socio-cultural processes. As such, littering needs to be studied within the unique setting, region and culture of the place it occurs (Schultz et al., 2013), include an understanding of the social drivers of such litter (Slavin et al., 2012) and devise measures tailored to particular circumstances (RPA, 2013). The situated research carried out in Jisr suggests an additional dimension to these findings by showing that the underlying narratives and politics playing out at a local level need to be understood in order to identify which interventions are likely to be effective and which are not. This will enable a more targeted and effective use of public funding as well as a greater likelihood of success in reducing marine litter.

\section{Acknowledgements}

The authors are grateful to the interviewees for their time and contributions. We acknowledge the translation and research assistance provided by Mona Sabbah and Eden Barnoy. We thank the Quebec Labrador Foundation (7200750) for partial funding of this research through support for the MarCoast Ecosystems Integration Lab (http://portman.net.technion.ac.il/). 


\section{References}

Alkalay, R., Pasternak, G., Zask, A., 2007. Clean-coast index - a new approach for beach cleanliness assessment. Ocean Coast. Manag. 50, 352-362.

Al-Khatib, I., 2009. Children's perceptions and behavior with respect to glass littering in developing countries: a case study in Palestine's Nablus district. Waste Manag. 29, 1434-1437.

Al-Khatib, I., Arafat, H., Daoud, R., Shwahneh, H., 2009. Enhanced solid waste management by understanding the effects of gender, income, marital status, and religious convictions on attitudes and practices related to street littering in Nablus-Palestinian territory. Waste Manag. 29, 449-455.

Al-Masroori, H.S., Al-Oufi, H., McShane, P., 2009. Causes and mitigations on trap ghost fishing in Oman: scientific approach to local fishers' perception. J. Fish. Aquat. Sci. 4 (3), 129-135.

Arafat, H., Al-Khatib, I., Daoud, R., Shwahneh, H., 2007. Influence of socio-economic factors on street litter generation in the Middle East: effects of education level, age, and type of residence. Waste Manag. Res. 25 (4), 363-370.

Arlozorov, M., 2016. How Israel Destroyed the Place that could Have Been like Sinai. The Marker. Available online from. http://www.themarker.com/news/1.2958969.

Bacchi, C., 2012. Why study problematizations? Making politics visible. Open J. Polit. Sci. 2 (1), 1-8.

Bator, R., Bryan, A., Schultz, P.W., 2011. Who gives a hoot? Intercept surveys of litterers and disposers. Environ. Behav. 43, 295-315.

Bilkovic, D.M., Havens, K., Stanhope, D., Angstadt, K., 2014. Derelict fishing gear in Chesapeake Bay, Virginia: Spatial patterns and implications for marine fauna. Mar. Pollut. Bull. 80, 114-123.

Bonaiuto, M., Breakwell, G.M., Cano, I., 1996. Identity processes and environmental threat: the effects of nationalism and local identity upon perception of beach pollution.

J. Community Appl. Soc. Psychol. 6, 157-175.

Bryman, J., 2008. Social Research Methods. third ed. Oxford University Press, Oxford. Burawoy, M., 1998. The extended case method. Sociol. Theory 16 (1), 4-33.

Butler, J., Gunn, R., Berry, H., Wagey, G., Hardesty, B., Wilcox, C., 2013. A value chain analysis of ghost nets in the Arafura Sea: identifying trans-boundary stakeholders, intervention points and livelihood trade-offs. J. Environ. Manag. 123, 14-25.

CBS, 2013a. Central Bureau of Statistics. Local Councils' Profile: Jisr a Zarqa. http://www. cbs.gov.il/publications15/local_authorities13_1609/pdf/447_0541.pdf (in Hebrew). 
CBS, 2013b. Central Bureau of Statistics. Characterization and Classification of Geographical Units by the Socio-economic Level of the Population 2008. http://www.cbs.gov.il/ reader/newhodaot/hodaa_template_eng.html?hodaa=201324087 (Press Release).

CBS, 2013c. Central Bureau of Statistics. Characterization and Classification of Geographical Units by the Socio-Economic Level of the Population 2008.

http://www.cbs.gov.il/publications13/1530/pdf/e_print.pdf.

Checkland, P., Poulter, J., 2006. Learning for Action. A Short Definitive Account of Soft Systems Methodology and Its Use for Practitioners, Teachers and Students. Wiley, West Sussex.

Chen, C.-L., 2015. Regulation and management of marine litter. In: Bergmann, M., Gutow, L., Klages, M. (Eds.), Marine Anthropogenic Litter. Springer, Switzerland, pp. 395-428. Cinnirella, S., Sardà, R., Suárez de Vivero, J.L., Brennan, R., Barausse, A., Icely, J., Luisetti, T., March, D., Murciano, C., Newton, A., O'Higgins, T., Palmeri, L., Palmieri, M.G., Raux, P., Rees, S., Albaigés, J., Pirrone, N., Turner, K., 2014. Steps towards a shared governance response for achieving good environmental status in the Mediterranean Sea. Ecol. Soc. 19:47. http://dx.doi.org/10.5751/ES07065-190447.

CleanSea, 2015. CleanSea, a Scientific Voyage Into the Problem of Marine Litter and What We Can Do About It. Available online at. https://www.youtube.com/watch?v=Ju1dvP4kcgw (relevant section @13:38-15:17).

Creswell, J.W., 1998. Qualitative Inquiry and Research Design: Choosing Among five Traditions. Sage Publications Inc, Thousand Oaks, California.

DG ENV, 2011. European Commission DG ENV. Plastic Waste in the Environment. Revised Final Report.

Eastman, L.B., Núñez, P., Crettier, B., Thiel, M., 2013. Identification of self-reported user behavior, education level, and preferences to reduce littering on beaches - a survey from the SE Pacific. Ocean Coast. Manag. 78, 18-24.

EcoOcean, 2015. National Assessment of Abandoned/lost Fishing Gear. A Contribution to the Implementation of the UNEP/MAP Regional Plan on Marine Litter Management in the Mediterranean - Israel.

EEA, 2015. European Environment Agency. State of Europe's Seas. EEA Report No. 2/2015, http://dx.doi.org/10.2800/64016. Available online from, http://www.eea.europa.eu/publications/state-of-europes-seas.

FAO, 2005. Food and Agriculture Organisation. Fisheries and Aquaculture Topics. Small- scale and Artisanal Fisheries. Topics Fact Sheets. Available online from. http://bit.ly/ 2c33G35. 
Foucault, M., 1984. Polemics, politics and problematizations, based on an interview con- ducted by Paul Rabinow. In: Davis, L. (Ed.), (Trans.), Essential Works of Foucault vol. 1. New Press, Ethics, New York Available online from. http://foucault.info/foucault/interview.html.

Frangoudes, K., Marugán-Pintos, B., Pascuál-Fernandez, J.J., 2013. Gender in Galician shellfisheries: transforming for governability. In: Bavinck, M., Chuenpagdee, R., Jentoft, S., Kooiman, J. (Eds.), Governability of Fisheries and Aquaculture. Theory and Applications. Springer, Dordrecht, pp. 241-261.

Frantzman, S., 2010. The Arab Settlement of Late Ottoman and Mandatory Palestine: New Village Formation and Settlement Fixation, 1871-1948. (Unpublished doctoral thesis). Hebrew University of Jerusalem.

Frantzman, S., Kark, R., 2011. Bedouin Settlement in Late Ottoman and British Mandatory Palestine: Influence on the Cultural and Environmental Landscape, 1870-1948. New Middle Eastern Studies. vol. 1:pp. 1-24 Available online from. http://www.brismes.ac.uk/nmes/?s=kark.

Galgani, F., Hanke, G., Maes, F., 2015. Global distribution, composition and abundance of marine litter. In: Bergmann, M., Gutow, L., Klages, M. (Eds.), Marine anthropogenic litter. Springer, Switzerland, pp. 29-56.

Gall, S.C., Thompson, R., 2015. The impact of debris on marine life. Mar. Pollut. Bull. 92: 170179. http://dx.doi.org/10.1016/j.marpolbul.2014.12.041.

GEF, 2012. Secretariat of the Convention on Biological Diversity and the Scientific and Technical Advisory Panel. Impacts of Marine Debris on biodiversity: Current Status and Potential Solutions. Montreal, Technical Series No. 67.

Gray, A., 2011. Worldviews. Int. Psychiatry 8 (3):58-60 Available online from. https://www.rcpsych.ac.uk/pdf/IPv8n3.pdf\#page=8.

Gregory, M., 2009. Environmental implications of plastic debris in marine settingsentanglement, ingestion, smothering, hangers-on, hitch-hiking and alien invasions. Philos. Trans. R. Soc. B Biol. Sci. 364:2013-2025. http://dx.doi.org/10.1098/rstb.2008.0265.

Hartley, B.L., Thompson, R.C., Pahl, S., 2015. Marine litter education boosts children's understanding and self-reported actions. Mar. Pollut. Bull. 90, 209-217.

Hardesty, B.D., Wilcox, C., Lawson, T.J., Lansdell, M., van der Velde, T., 2014. Understanding the Effects of Marine Debris on Wildlife. A Final Report to Earthwatch Australia. CSIRO.

Hardesty, B.D., Good, T.P., Wilcox, C., 2015. Novel methods, new results and science-based solutions to tackle marine debris impacts on wildlife. Ocean Coast. Manag. 115, 4-9. 
IPA, 2009. Israel Planning Authority - Haifa County. National Park and Nature Reserve in the Beach of Jisr-Az-Zarqa. Local Plan SH/782A.

Jambeck, J.R., Geyer, R., Wilcox, C., Siegler, T.R., Perryman, M., Andrady, A., Narayan, R., Law, K.L., 2015. Plastic waste inputs from land into the ocean. Science 347 (6223), 768-771.

Jentoft, S., 2007. Limits of governability: institutional implications for fisheries and coastal governance. Mar. Policy 31, 360-370.

Jentoft, S., Chuenpagdee, R., 2009. Fisheries and coastal governance as a wicked problem. Mar. Policy 33, 553-560.

Kamisher, E., 2015. Overlooked Arab-Israeli Beach Town Opens Its Doors to Tourists. Times of Israel. Available online from. http://www.timesofisrael.com/overlooked-arab-israeli-beachtown-opens-its-doors-to-tourists.

Kluckhohn, C., 1966. The scientific study of values and contemporary civilization. Zygon: J. Relig. Sci. 1 (3), 230-243.

Kooiman, J., Jentoft, S., 2009. Meta-governance: values, norms and principles, and the making of hard choices. Public Adm. 87, 818-836.

Kooiman, J., Bavinck, M., 2013. Theorizing governability - the interactive governance perspective. In: Bavinck, M., Chuenpagdee, R., Jentoft, S., Kooiman, J. (Eds.), Governability of Fisheries and Aquaculture. Theory and Applications. Springer, Dordrecht, pp. 9-30.

Koutsodendris, A., Papatheodorou, A., Kougiourouki, O., Georgiadis, M., 2008. Benthic marine litter in four Gulfs in Greece, Eastern Mediterranean; abundance, composition and source identification. Estuar. Coast. Shelf Sci. 77, 501-512.

Kühn, S., Bravo-Rebolledo, E.L., van Franeker, J.A., 2015. Deleterious effects of litter on marine life. In: Bergmann, M., Gutow, L., Klages, M. (Eds.), Marine Anthropogenic Litter. Springer, Switzerland, pp. 75-116.

Kwakkel, J.H., Walker, W.E., Haasnoot, M., 2016. Coping with the wickedness of public policy problems: approaches for decision making under deep uncertainty. J. Water Resour. Plan. Manag. 142 (3):01816001. http://dx.doi.org/10.1061/(ASCE)WR.1943-5452.0000626.

Laist, D.W., 1997. Impacts of marine debris: entanglement of marine life in marine debris including a comprehensive list of species with entanglement and ingestion records. In: Coe, J., Rogers, D. (Eds.), Marine Debris: Sources, Impacts, and Solutions. Springer-Verlag, New York, pp. 99-139. 
Liffmann, M., Howard, B., O'Hara, K., Coe, J.M., 1997. Strategies to reduce, control, and minimize land-source marine debris. In: Coe, J.M., Rogers, D.B. (Eds.), Marine debris: Sources, impacts, and solutions. Springer, Berlin, pp. 381-390.

Mee, L.D., Jefferson, R.L., Laffoley, D., Elliot, M., 2008. How good is good? Human values and Europe's proposed Marine Strategy Framework Directive. Mar. Pollut. Bull. 56 (2), 187-204.

Mee, L., Cooper, P., Kannen, A., Gilbert, A.J., O'Higgins, T., 2015. Sustaining Europe's seas as coupled social-ecological systems. Ecol. Soc. 20 (1):1. http://dx.doi.org/10.5751/ES- 07143200101.

Morgan, D.L., 2008. In: Given, L. (Ed.), The SAGE Encyclopedia of Qualitative Research Methods. SAGE Publications, Thousand Oaks, California, pp. 815-816.

Munari, C., Corbau, C., Simeoni, U., Mistri, M., 2016. Marine litter on Mediterranean shores: analysis of composition, spatial distribution and sources in north-western Adriatic beaches. Waste Manag. 49, 483-490.

Nash, D., 1992. Impacts of marine debris on subsistence fishermen. An exploratory study. Mar. Pollut. Bull. 24 (3), 150-156.

Pasternak, G., Spanier, E., Zviely, D., Ribic, C.A., Van der Hal, N., Angel, D., Ariel, A., 2016. Research on Solid Waste Pollution Along the Israeli Coastline. EcoOcean Marine Re- search and Education.

http://www.ecoocean.org/AllSites/3/Assets/a\%20summary\%20of\%20a\%20research\%20on\%20 marine\%20debris\%20in\%20israel.pdf.

PCMP (n.d.) Proposed Comprehensive Master Plan Jisr-Az-Zarka 353-0191023 (in Hebrew). Rapoport, M., 2010. A Classic Zionist Story Haaretz, 10 June 2010. Available online at. http://www.haaretz.com/israel-news/a-classic-zionist-story-1.295418.

Ritchie, J., Lewis, J., MacNaughton Nicholls, C., Ormston, R., 2014. Qualitative Research Practice: A Guide for Social Science Students and Researchers. Sage Publications Ltd, London.

Rittel, H.W.J., Webber, M.W., 1973. Dilemmas in a general theory of planning. Policy. Sci. 4 (2), 155-169.

Anti-littering instruments: feasibility study of introducing instruments to prevent littering. Final Report for the European Commission, ENV.D.2/ETU/2011/0042. RPA.

Ryan, P.G., 2015. A brief history of marine litter research. In: Bergmann, M., Gutow, L., Klages, M. (Eds.), Marine Anthropogenic Litter. Springer, Switzerland, pp. 1-25. 
Schultz, P.W., Tabanico, J., Rendon, T., 2008. Normative beliefs as agents of influence: basic processes and real-world applications. In: Prislin, R., Crano, W. (Eds.), Attitudes and Attitude Change. Psychology Press, New York, pp. 385-409.

Schultz, P.W., Bator, R.J., Large, L.B., Bruni, C.M., Tabanico, J.J., 2013. Littering in context: personal and environmental predictors of littering behavior. Environ. Behav. 45 (1), 35-59.

Sidani, Y., 2005. Women, work, and Islam in Arab societies. Women Manage. Rev. 20, 498-512.

Slavin, C., Grage, A., Campbell, M.L., 2012. Linking social drivers of marine debris with actual marine debris on beaches. Mar. Pollut. Bull. 64, 1580-1588.

Song, A.M., Chuenpagdee, R., Jentoft, S., 2013. Values, images and principles: what they represent and how they may improve fisheries governance. Mar. Policy 40, 167-175. STAP, 2011. Marine Debris as a Global Environmental Problem: Introducing a Solutions Based Framework Focused on Plastic. A STAP Information Document. Global Environment Facility, Washington, DC.

Thompson, R.C., 2015. Microplastics in the marine environment: sources, consequences and solutions. In: Bergmann, M., Gutow, L., Klages, M. (Eds.), Marine Anthropogenic Litter. Springer, Switzerland, pp. 185-200.

UNEP-MAP, 2008. United Nations Environmental Program-Mediterranean Action Plan. Annex III. Almeria Declaration. 15th Ordinary Meeting of the Contracting Parties to the Convention for the Protection of the Marine Environment and the Coastal Region of the Mediterranean and Its Protocols. UNEP-MAP, Athens, Greece.

http://195.97.36.231/dbases/acrobatfiles/08IG17_10_Ann3_AlmeriaDeclaration_Eng.pdf.

UNEP, 2009. Marine Litter: A Global Challenge. UNEP, Nairobi.

UNEP, 2012. State of the Mediterranean Marine and Coastal Environment. Highlights for Policy Makers.

UNEP-MAP, 2014. Regional plan on marine litter management in the Mediterranean. 16th Regional Seas Co-ordination Meeting. Athens, 29 September-1 October 2014. http://www.unep.org/ecosystemmanagement/water/regionalseas40/Portals/50221/MAP\%20D elopment\%20of\%20a\%20Regional\%20Action\%20Plan\%20on\%20Marine\%20Litter\%20for\%20th e\%20Mediterranean\%20Sea\%20-\%20Gaetano\%20Leone.pdf.

Van de Vijver, F., Leung, K., 1997. Methods and data analysis of comparative research. In: Berry, J.W., Poortinga, Y.H., Pandey, J. (Eds.), Handbook of Cross-cultural Psychology: Theory and Method, second ed. vol. 1. Allyn \& Bacon, Needham Heights, MA, pp. 257-300. 
Vegter, A., Barletta, M., Beck, C., Borrero, J., Burton, H., Campbell, M., Eriksen, M., Eriksson, C., Estrades, A., Gilardi, K., Hardesty, B.D., Assunçao I do Sul, J., Lavers, J., Lazar, B., Lebreton, L., Nichols, W.J., Ramirez Llodra, E., Ribic, C., Ryan, P.G., Schuyler, Q., Smith, S.D.A., Takada, H., Townsend, K., Wabnitz, C., Wilcox, C., Young, L., Hamann, M., 2014. Global research priorities for the management and mitigation of plastic pollution on marine wildlife. Endanger. Species Res. 25:224-247. http://dx.doi.org/10.3354/esr00623.

Veiga, J.M., Vlachogianni, T., Pahl, S., Thompson, R.C., Kopke, K., Doyle, T.K., Hartley, B.L., Maes, T., Orthodoxou, D.L., Loizidou, X.I., Alampei, I., 2016. Enhancing public awareness and promoting co-responsibility for marine litter in Europe: The challenge of MARLISCO. Mar. Pollut. Bull. 102 (2):309-315. http://dx.doi.org/10.1016/j.marpolbul.2016.01.03.

Victor, D.G., 2015. Embed the social sciences in climate policy. Nature 520, 27-29.

Voyer, M., Gollan, N., Barclay, K., Gladstone, W., 2015. 'It's part of me'; understanding the values, images and principles of coastal users and their influence on the social acceptability of MPAs. Mar. Policy 52, 93-102.

Wallace, B., 1990. How much do commercial and recreational fishermen know about marine debris and entanglement? Phase 1. In: Shomura, R.S., Godfrey, M.L. (Eds.),

Proceedings of the Second International Conference on Marine Debris, 2-7 April 1989, Honolulu, Hawaii Available online from. https://swfsc.noaa.gov/publications/TM/SWFSC/NOAA-TM-NMFS-SWFSC-154_P1140.PDF.

Wyles, K.J., Pahl, S., Thomas, K., Thompson, R.C., 2015. Factors that can undermine the psychological benefits of coastal environments: exploring the effect of tidal state, presence and type of litter. Environ. Behav. 1-32.

Yin, R.K., 1994. Case Study Research Design and Methods. second ed. SAGE Publications, Thousand Oaks, California.

Zayadskaya, M., Welzel, C., 2013. Values, repression, and subversion: incumbent defeat in competitive autocracies. World Values Res. 6 (2), 45-75. 